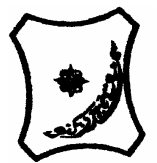

Bayero Journal of Pure and Applied Sciences, 4(2): 164 - 168

Received: August, 2011

Accepted: December, 2011

ISSN $2006-6996$

\title{
SESAME (SESAMUM INDICUM L.) SEED OIL METHODS OF EXTRACTION AND ITS PROSPECTS IN COSMETIC INDUSTRY: A REVIEW
}

\author{
Warra, A.A. \\ Department of Biochemistry, Kebbi State University of Science \& Technology, P.M.B.1144 Aliero, Nigeria. \\ aliyuwarra@yahoo.com
}

\begin{abstract}
The relative abundance of sesame seed oil coupled with the little knowledge of its cosmetic usage prompted the need for this review. The aim is to discuss the various extraction methods of the sesame seed oil and its industrial applications particularly its application in cosmetic production. The review focused mainly on the traditional African methods of extraction and the utilization of the seed oil in soap making and production of skin moisturizers.
\end{abstract}

Key words: Sesame seed, oil extraction, export, soap, skin moisturizers.

\section{INTRODUCTION}

Sesame (Sesamum indicum L.) from Pedaliaceae, is an important oil seed crop being cultivated in the tropics and the temperate zone of the world. (Biabani, and Pakniyat, 2008 ). It is one of the oldest oil crops and is widely cultivated in Asia and Africa. (Ali et al., 2007).It was a highly prized oil crop of Babylon and Assyria at least 4000 years ago (Ross, 2005). Sesame oil, otherwise also referred to as gingelly oil, is one of the major sources of edible oil in India and is culturally associated from the Vedic period. The Sanskrit word for oil, taila is derived from the Sanskrit word for sesame tila. (Shanthasheela et al., 2007). It is called "sesame" internationally, while it is called "benniseed" in West Africa; "simsim" in East Africa and "Till" in India.Within Nigeria it is called different names in different localities. It is generally called "ridi" in the Northern States. The Igalas, Idomas and Tivs of Benue State call it "Igogo", "Ocha" and "Ishwa" respectively. The Ibos call it "isasa" and Yorubas call it "Ekuku" or "Eeku" in parts of Ogun, Ondo and Oyo states and Ilorin in Kwara State. (Aboje, 2011). Natural sesame oil derived from good quality seed has a very pleasant flavour and can be consumed without further purification. The natural oil has excellent stability due to the presence of high levels of natural antioxidants (Lyon, 1972). Report has shown the impact of environment on the seed yield. Seed Production Environment and Potential Seed Longevity of Rain-fed Sesame (Sesamum indicum L.) Genotypes was reported by Adebisi, et al.,(2011). The oil is used widely in the some injectable drug formulations. The lignans such as sesamin, episesamin, sesaminol and sesamolin are major constituents of sesame oil and all have chemically methylenedioxyphenyl group (Gokbulut, 2010). It ranks ninth among the top thirteen oilseed crops which make up $90 \%$ of the world production of edible oil.( Adeola et al., 2010).

The oil is also useful in the industrial preparation of perfumery, cosmetics (skin conditioning agents and moisturizers, hair preparations, bath oils, hand products and make-up), pharmaceuticals (vehicle for drug delivery), insecticides and paints and varnishes (Chemonics International Inc., 2002). Sesame seed has higher oil content( around 50\%) than most of the known oil seeds (Hwang, 2005) The seed has 40-60 per cent of oil with almost equal levels of oleic (range $33-50 \%$, typically $41 \%$ ) and linoleic acids (range $33-50 \%$, typically $43 \%$ ) and some palmitic acid (range 7-12\%, typically $9 \%$ ) and stearic acid (range 3-6\%, typically 6\%) (Gunstone, 2004). Sesamum indicum L. oil can be classified in the oleiclinoleic acid group. The dominant saturated acids were palmitic (up to $8.58 \%$ ) and stearic (up to $5.44 \%$ ) (Nzikou et a.l,2009). Chemical analysis of varieties of sesame seed was reported. An analytical comparison of the biochemical composition of Black Sesame (BS) and White Sesame (WS) produced in China was carried out by Kanu,(2011). Mohammed and Hamza, (2008) reported some physical and chemical characteristics of oils extracted from sesame seed (Table1).

Table 1: Some physical and chemical characteristics of oils extracted from sesame seed*.

\begin{tabular}{cccc}
\hline $\mathbf{S} / \mathbf{N}$ & $\begin{array}{c}\text { Analysis/Physical and } \\
\text { chemical characteristics }\end{array}$ & $\mathbf{W}$ & $\mathbf{R}$ \\
\hline 1 & Colour & White & Red \\
2 & Iodine value $\left(\mathrm{gI}_{2} / 100 \mathrm{~g}\right)$ & 103 & 116 \\
3 & Oil content $(\%)$ & 48 & 50 \\
4 & Specific gravity $\left(\mathrm{g} / \mathrm{cm}^{3}\right)$ & 0.915 & 0.923 \\
5 & Acid value $(\mathrm{mg} \mathrm{KOH} / \mathrm{g})$ & 0.5 & 0.45 \\
6 & Peroxide value $(\mathrm{Meq} \mathrm{KOH} / \mathrm{g})$ & 8 & 7.45 \\
7 & Saponification value $(\mathrm{mg} \mathrm{KOH} / \mathrm{g})$ & 189 & 191 \\
\hline 8 & Cyanide test & Negative & Negative \\
\hline
\end{tabular}

${ }^{*}$ The values are mean of three replicates 


\section{Production}

Sudan, Uganda, Nigeria and Tanzania were among the ten top producers of sesame from the statistical data (Chemonics International Inc., 2002).The largest producers are China and India, each with an annual harvest around 750,000 tonnes followed by Myanmar (425,000 tonnes) and Sudan (300,000 tonnes). These figures are only rough estimates of the situation as sesame is a smallholder crop and much of the harvest is consumed locally, without record of the internal trade and domestic processing. (Chemonics International Inc., 2002).

\section{Export}

Sudan, Ethiopia, Nigeria and Tanzania were among the ten top exporters of sesame from the statistical data (Chemonics International Inc., 2002).

Global exports of sesame seed are estimated to have reached 657,000 tonnes in 2000, having risen from 427,000 tonnes in 1988. The 2000 exports were valued at $\$ 478 \mathrm{mn}$. Figure 3 shows the rise of Africa over the last ten years as a supplier of sesame seed and also the growth of Indian output.

\section{Oil Extraction}

\section{Hot water flotation}

Hot water flotation is a traditional method in Uganda and Sudan for the extraction of sesame oil. The following is a description of a laboratory method, as details of the traditional method have not been located. Sesame seed is ground to a paste and heated to $80-90^{\circ} \mathrm{C}$ for $15 \mathrm{~min}$. Enough boiling water is then added to suspend the ground seed on stirring. The mixture is boiled with stirring for $15 \mathrm{~min}$. After cooling the upper oil layer is separated off and dried by heating. The oil recovery from $0.5 \mathrm{~kg}$ seed is 108 $\mathrm{ml}$, equivalent to an oil extraction efficiency of $41 \%$. (Natural Resources Institute, 1995).

\section{Bridge press}

Laboratory trials at NRI have demonstrated that sesame seed is suitable for processing in a bridge press. However, no results of its application in the field are available. In the laboratory trials, sesame seeds were ground to a paste using a powered mincer incorporating a plate with $2 \mathrm{~mm}$ holes. It is important to grind the seeds as finely as possible. Oil extraction was improved by the addition of water, and optimum oil recovery was achieved at a moisture content range of $11-13 \%$. Yields of over $70 \%$ were recorded with sesame paste containing $12.7 \%$ moisture pre-heated to $50^{\circ} \mathrm{C}$ before pressing (Figure 1 ) (Natural Resources Institute, 1995).

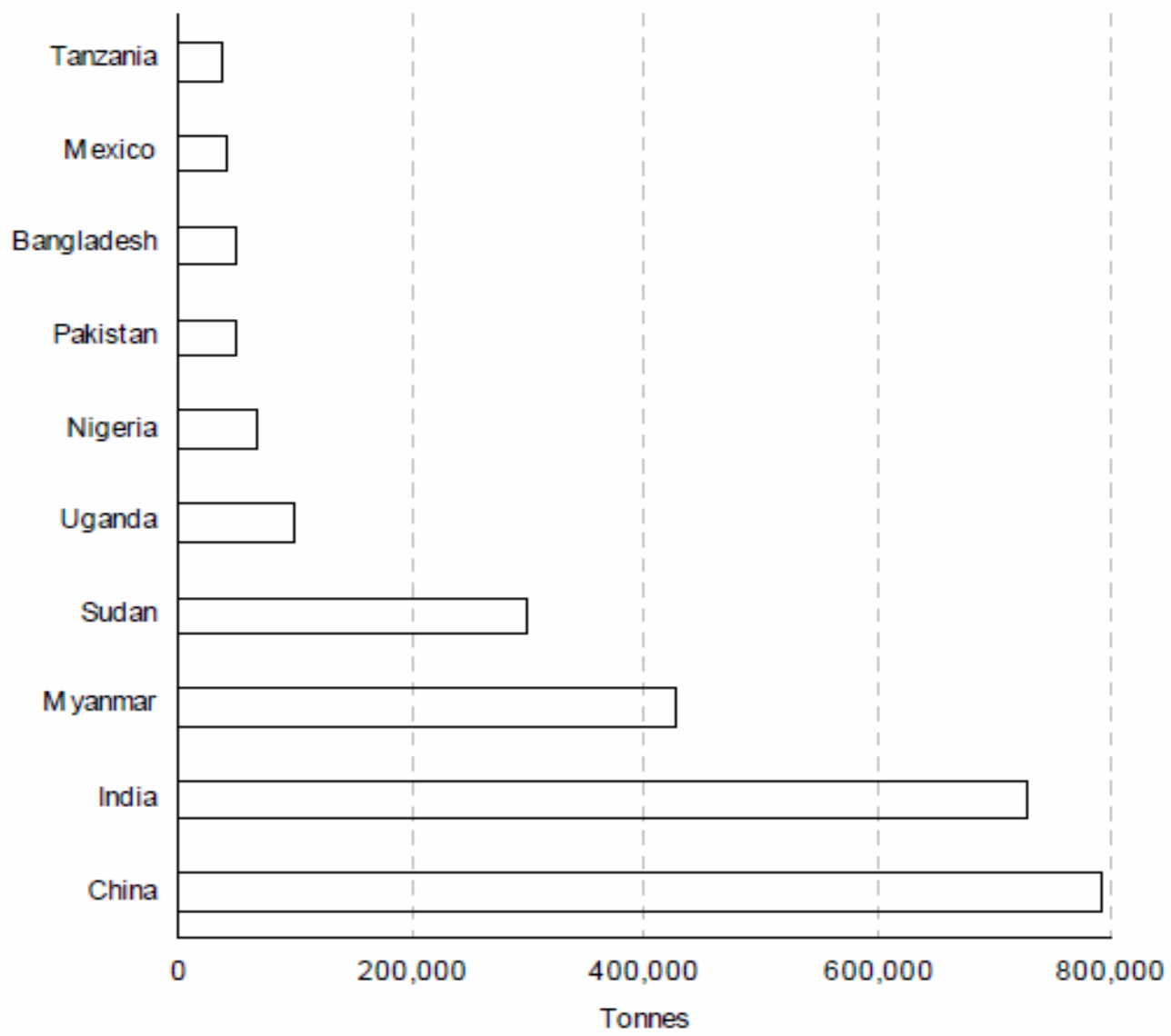

Figure 1: TopTen Producers of Sesame seed, 2001 (Chemonics International Inc., 2002) 
Bajopas Volume 4 Number 2 December, 2011

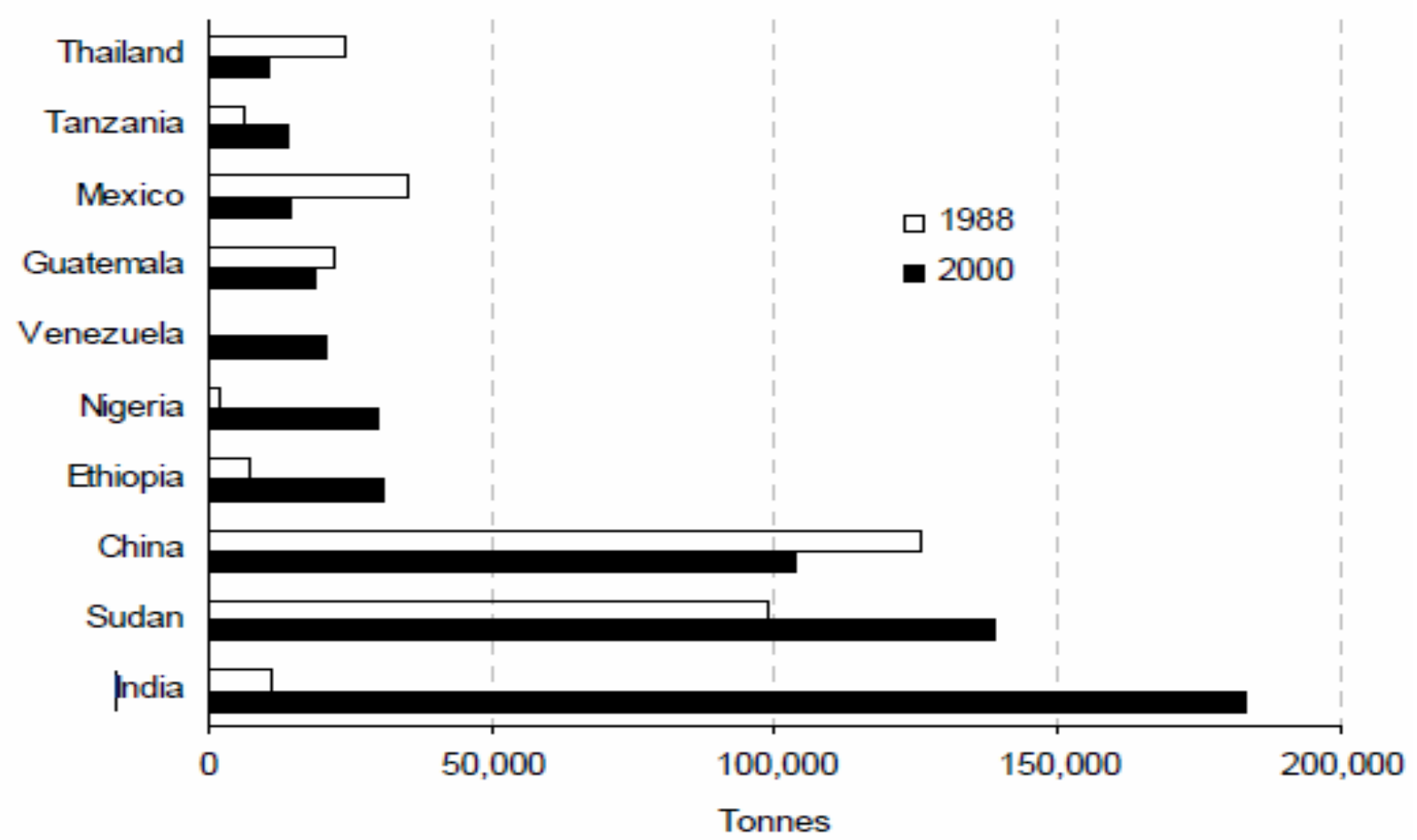

Figure 2 : Top Ten Exporters of Sesame seed, 2001 (Chemonics International Inc., 2002)

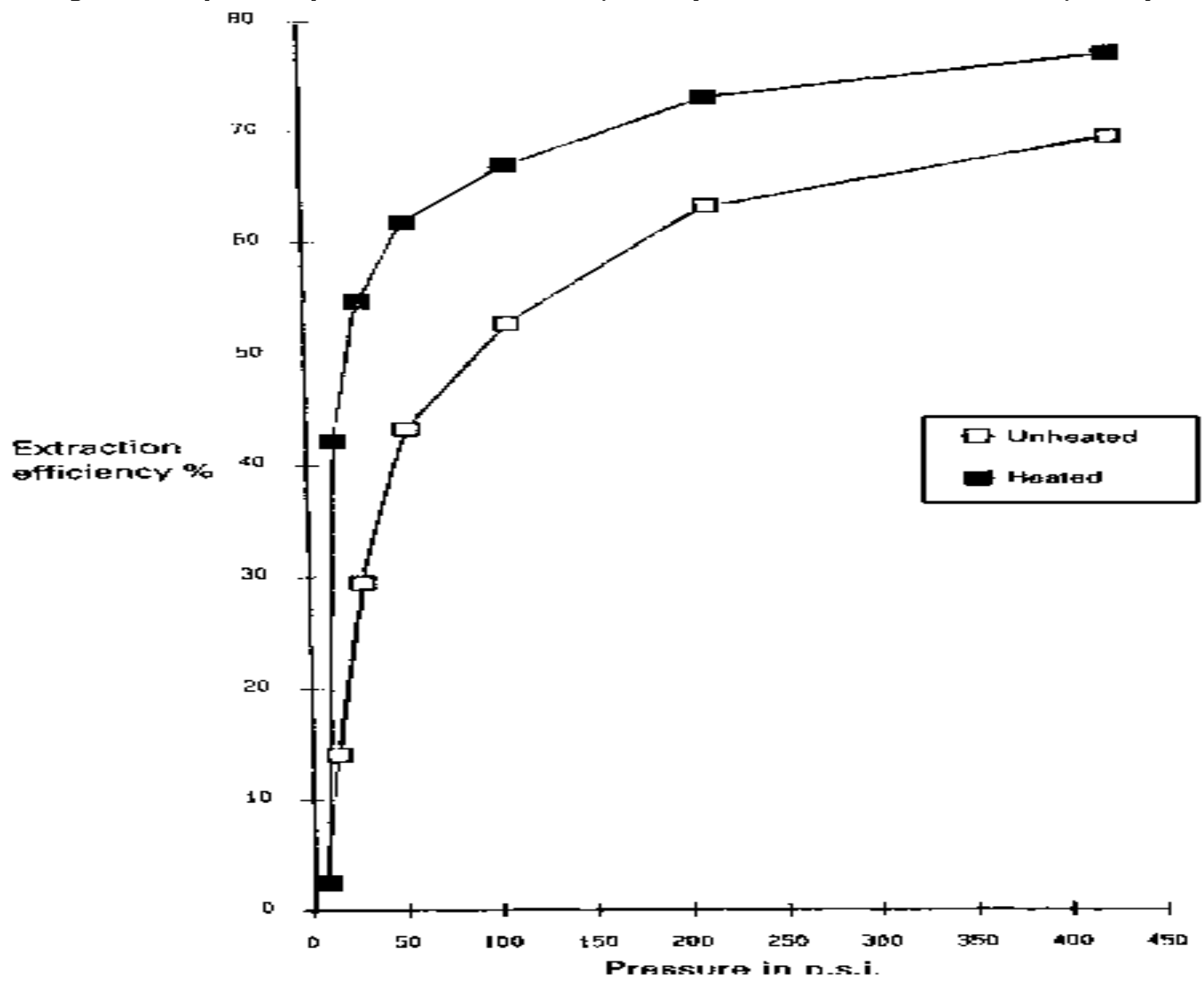

Figure 3:. Extraction efficiencies of sesame seed paste at $12.7 \%$ moisture heated to $50^{\circ} \mathrm{C}$ and unheated before pressing (NRI, 1995). 


\section{Ram press}

Work in Tanzania has indicated that sesame is suited to processing in the ram press. Pre-grinding is not required but pre-heating the seed by warming in the sun, preferably on metal roofing sheets, is strongly recommended. Use of the CAPU press gave an oil extraction efficiency of $57.5 \%$ in terms of clarified oil. The oil production rate was a little over $2.2 \mathrm{l} / \mathrm{in}$. The oil extraction efficiency of the smaller CAMARTEC press under similar operating conditions was $62 \%$, and the oil production rate was $1.5 \mathrm{l} / \mathrm{in}$. ( Natural Resources Institute, 1995).

\section{The ghani process (Sudan)}

The following traditional method was described by Kamel-Eldin et al. (1992). The addition of oil to aid the extraction process is of particular interest. Sesame seeds (12 kg, oil content $53.1 \%$ MFB) were ground in a camel-powered ghani with 0.5 I of water. Oil release was observed after $30 \mathrm{~min}$. when the temperature of the mass was $41^{\circ} \mathrm{C}$. After $40 \mathrm{~min} ., 2$ I of oil previously extracted (temperature $46^{\circ} \mathrm{C}$ ) were added to assist extraction. Extraction was complete in $55-60$ min., giving approximately $5 \mathrm{I}$ of oil (temperature $50^{\circ} \mathrm{C}$ ). ( Natural Resources Institute, 1995).

\section{Laboratory method of Extraction}

Modern laboratory methods normally employed in the analysis of oils usually includes soxhlet extraction usually using n-hexane and the enzymatic extraction.

Extraction of crude sesame oil by the use of a soxhlet extractor with $\mathrm{n}$-hexane solvent was reported by Mohammed and Hamza( 2008 ). Extraction of sesame oil from sesame seeds using supercritical $\mathrm{CO} 2$ was carried out by Doker et al., ( 2010)

\section{Cosmetic Utilization}

Among the commonly used occlusive moisturizers include sesame seed oil (Tabor and Blair, 2009). Occlusive materials comprise vegetable oils, triglycerides, mineral oil, natural or synthetic waxes, fatty acid esters, lanolin oil and its derivatives, and polydimethylsiloxanes, among others. They form an occlusive layer on the skin, keeping water inside upper stratum corneum layers and consequently acting as moisturizers. ( Barel et al., 2001). It also belongs to emmolients and refatteners (Barel et al., 2001). Emollients are also described as refatting additives or refatteners in the case of bath products. The word refattener refers to substances improving the lipid content of the upper layers of the skin; they prevent defatting and drying out of the skin. Several emollients showing strong lipophilic character are identified as occlusive ingredients; they are fatty/oily materials that remain on the skin surface and reduce transepidermal water loss. (Barel et al., 2001).

\section{Simple Technology of Soap production from Sesame seed oil}

A simple technology for the Production of Soap from Northern Nigerian Sesame (Sesamum indicum,L.) Seed oil was reported by Warra et al.,(2011). This is in line with the cold-process alkali hydrolysis which is a simple adoptable technology reported by Warra, (2011), (Warra et al., 2010); Warra, (2009); (Warra et al., 2009a) and (Warra et al., 2009b). The foam height of the soap produced was $4.8 \mathrm{~cm}$ (Table 5 and Fig 2 ) lower than that of Jatropha, higher than that of all other soap solutions analyzed.

Table 2: Foam ability as a function of foam height of the various soap samples (Warra, 2011)

\begin{tabular}{lc}
\hline Soap sample & Foam height $\mathbf{( c m )}$ \\
\hline Castor oil based soap & 1.6 \\
Castor glycerine soap & 1.4 \\
Cotton oil soap & 4.5 \\
Jatropha oil based soap & 5.4 \\
Neem oil soap & 2.0 \\
Sesame oil soap & 4.8 \\
Shea nut fat soap & 4.2
\end{tabular}

*The values are mean of triplicates determinations.

The overall reaction of triacylglycerol saponification (Figure 3) can be thought of as occurring in two steps. The first step is the hydrolysis of the ester linkages to produce glycerol and three fatty acid molecules: Fat or oil $+3 \mathrm{H}_{2} \mathrm{O} 3$ fatty acids + glycerol. The second step involves a reaction between the fatty acid molecules and base (usually $\mathrm{NaOH}$ ) in the alkali solution. This is an acid - base reaction that produces water plus salts: 3 fatty acids $+3 \mathrm{NaOH}-\rightarrow 3$ fatty acid salts $+3 \mathrm{H}_{2} \mathrm{O}$<smiles>[R]C(=O)OCC(COC([R])=O)OC([R])=O</smiles>

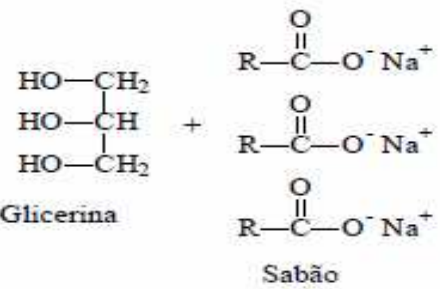

Figure 3 : Saponification réaction (Contarini et al., 2008)

\section{CONCLUSION}

Sesame as a valued oil seed appears to have numerous industrial applications. It is therefore important to fully develop Industrial processing and utilization of sesame at a substantial quantity to meet the current demands. 
In addition to other uses of the oil, like cooking as well as for medicinal purposes such as the treatment

\section{REFERENCES}

Adebisi, M.A., Ajala,M.O. and Kehinde,T.O.(2011). Seed Production Environment and Potential seed Longevity of Rain-fed Sesame (Sesamum indicum L.) Genotypes. Research Journal of Seed Science. 4: 166-173.

Aboje, P., (2011) Production \& export of sesame seed oil. Accessed http://www.scribd.com/doc/18106354/Productio n-Export-of-Sesame-Seed-Oil 16/4/2011

Adeola,Y. B., Augusta, C. O. and Oladejo,T. A.(2010). Proximate and mineral composition of whole and dehulled Nigerian sesame seed. African Journal of Food Science and Technology. 1(3): 071-075.

Ali, G.M., Yasumoto,S. and Seki-Katsuta, M. (2007). Assessment of genetic diversity in sesame Sesamum indicum L.) detected by Amplified Fragment Length Polymorphism markers. Electronic Journal of Biotechnology. 1(1)

Barel, A.O., Marc Paye, M. and. Maibach, H.I. (2001). Handbook of Cosmetic Science and Technology. $2^{\text {nd }}$ Edition Marcel Dekker, Inc. 270 Madison Avenue, New York. Pp 401-402

Biabani, A.R and Pakniyat, H. (2008). Evaluation of seed yield-related characters in sesame(Sesamum indicum L.) using factor and path analysis. Pakistan Journal of Biological Sciences. 11: 1157-1160.

Chemonics International Inc. (2002). Overview of the Nigerian Sesame Industry. Prepared for The United States Agency for International Development (USAID)/Nigeria.P8.

Contarini, J.M. and Waldman, W.R.(2008). Itinerant Museum of Chemistry History: The Soap. International Journal of Hands-on Science. 1646-8937

Doker,O., Salgin,U., Yildiz ,N., Aydog 'mus,M. and Calimli,A.(2010). Extraction of sesame seed oil using supercritical $\mathrm{CO} 2$ and mathematical modeling. Journal of Food Engineering 9: 360-366

Gokbulut , C. (2010). Sesame Oil: Potential Interaction with P450 Isozymes. Journal of Pharmaceutical Toxicology, 5: 469-472

Gunstone, F.D.(2004). The Chemistry of Oils and Fats: Sources, Composition, Properties and Uses. $1^{\text {st }}$ Edition. Blackwell Publishing Ltd, 9600 Garsington Road, Oxford OX4 2DQ, UK. P8

Hwang, L.S. (2005).Vegetable Oils (ed) in Bailey's Industrial Oil and Fat Products, $6^{\text {th }}$ Edition, Vol.1. Edited by Fereidoon Shahidi. John Wiley \& Sons, Inc. p1178

Kamel-Eldin, A., Yousif, G., Iskander, G. M. and Appelqvist, L.A., (1992). Seed lipids of Sesamum indicum, L. and related wild species in Sudan: fatty acids and triacylglycerols. Fat Science and Technology, 94(7): 254-259. of ulcers and burns, the oil extract could equally be used in making soap and skin moisturizers.

Kanu , P.J. (2011). Biochemical Analysis of Black and White Sesame Seeds from China. American Journal of Biochemistry and Molecular Biology 1: $145-157$.

Lyon, C. K.(1972) .Sesame: current knowledge of composition and use. Journal of American Oil Chemists Society, 49(4): 245-249.

Mohammed,M.I. and Hamza, Z.U.(2008). Physicochemical Properties of Oil Extracts from Sesamum Indicum L. Seeds Grown in Jigawa State Nigeria. Journal of Applied Science and Environmental Management 12(2): 99 - 101

Natural Resources Institute (1995). Small Scale Vegetable Oil Extraction. Accessed at http://www.appropedia.org/Original:Small_Scal e_Vegetable_Oil_Extraction 15/7/2011

Nzikou, J.M., Matos, .L., Bouanga-Kalou,.G., Ndangui,.C.B. ， Pambou-Tobi,N.P.G. Kimbonguila, A. Silou, T., Linder, $M$ and Desobry,S. (2009). Chemical Composition on the Seeds and Oil of Sesame (Sesamum indicum L.) Grown in Congo-Brazzaville. Advance Journal of Food Science and Technology. 1(1): 6-11

Roos, I.A.( 2005) .Medicinal Plants of the World, vol. 3: Chemical Constituents, Traditional and Modern Medicinal Uses. Humana Press Inc., Totowa, NJ. P488

Shanthasheela, M.N., Subbiah,V.R. and Nair,S. (2007). Sesame Village. M.S. Swaminathan Research Foundation, Chennai - 600113, India. p1

Tabor, A. and Blair,R.(2009). Nutritional Cosmetics: Beauty from within. Elsevier Inc. Linacre House, Jordan Hill, Oxford OX2 8DP, UK. p 367

Warra, A.A.( 2011). Cosmetic Potentials of African Shea Nut (Vitellaria paradoxa) Butter. Current Research in Chemistry. 3(2): 80-86

Warra, A.A., Suraj, L.G.and Jega, S.A.( 2011). Production of Soap from Northern Nigerian Sesame (Sesamum indicum,L.) Seed oil. Bayero Journal of Pure and Applied Science. 4(1):180-183

Warra, A.A., Hassan, L.G. Gunu, S.Y and Jega, S.A. (2010). Cold- Process Synthesis and Properties of Soaps Prepared from Different Triacylglycerol Sources. Nigerian Journal of Basic and Applied Sciences. 18: 315-321

Warra,A.A. (2009). Extraction and Chemical Analysis of Indigenous Shea nut oil. Proceedings of the $1^{\text {st }}$ National conference of the Academic staff Union of Polytechnics. WUFP

Chapter, Nigeria. Pp160-162

Warra,A.A.,Gunu,S.Y., Jega,S.A. and Aisha,J.A.(2009a). Soap production from shea nut butter. International Journal of Natural and Applied Sciences 5 : 410-412.

Warra, A.A., Hassan, L.G and Gunu, S.Y. ( 2009b) . Chemical Analysis of some selected fats and oils. International Journal of Tropical Agriculture and Food System . 3: 300-302 